\title{
UNIVERSITY VIRTUAL TECHNOPARK IS AN ENVIRONMENT FOR INNOVATIVE DEVELOPMENT OF SCIENCE
}

\author{
Suleymanov Akif Shamil oglu*, Doctor of Technical Sciences, Professor \\ Akhmedova Metanet Israil gizi, Ph.D., Associate Professor \\ Mammedova Galiba Rza gizi, Ph.D., Associate Professor \\ Azerbaijan Technological University (UTECA), Azerbaijan, Ganja \\ *E-mail: matanat a@mail.ru
}

\begin{abstract}
The implementation of the concept of creating a university virtual technology park proposed in this article will contribute to the expansion of the innovative segment of the Azerbaijani economy, client-oriented innovation projects, shortening the time at project development stages, improving the quality of project teams, attracting international experience and experts, significantly increasing the chances of technology projects.
\end{abstract}

\section{KEY WORDS}

Customer orientation, technology, incubator, cluster, transfer, infrastructure, investors.

With the aim of creating innovative economy in the country, modern realities require the development of an applied scientific and search mechanism in accordance with market demand, as well as the strengthening of the connection between science and production. This may be due to the emergence of innovative zones and technology parks for the development and application of science-intensive products, development of innovative production, strengthening measures in the direction of transfer and assimilation of advanced technologies. On the other hand, the birth of technoparks with modern production infrastructure is aimed at building modern complexes for developing new information technologies and conducting research, at increasing competitiveness, and ultimately, at the continuous and sustainable development of the country's economy [1].

The emergence of technology parks, as well as the continuous development of the non-oil sector of the country, is of great importance in solving such important tasks as the attraction of modern technologies and investments, increasing production of products by regions, and providing the working-age population with work. According to the exemplary situation, the technopark is a site that has administrative structures and material and technical base, as well as the necessary infrastructure for the purpose of developing or improving innovative products and high technologies for the program of customer orientation of the conducted experimental research works and application of their results in industry, services and other fields. To regulate the activities of the technopark, first of all, it is necessary to put in order the allocated site, then it is necessary to create its infrastructure, incubator and technology transfer centre. Then, in accordance with the activities, it is necessary to create services connected with the conducting of research and experience design work for the preparation, development and improvement of high technology and innovative products. Technopark is a centre uniting the interests of the state, society, science and small business. The multiplicity of this concept allows us to draw two important conclusions. The first is that a multifactor model lies in the basis of the creation and development of the technopark. The second - the success of the development of this model depends on the interest of all participants. This includes the possibility of implementing scientific developments, gaining new knowledge and additional material earnings by the university staff and its students. The creation of technoparks, as can be seen from Fig. 1, on the one hand, promotes the development of knowledge-intensive industries, and, on the other hand, attracts new investors to the market. It should be noted that attracting investments will stimulate the development of the region where the technopark is located [2]. 


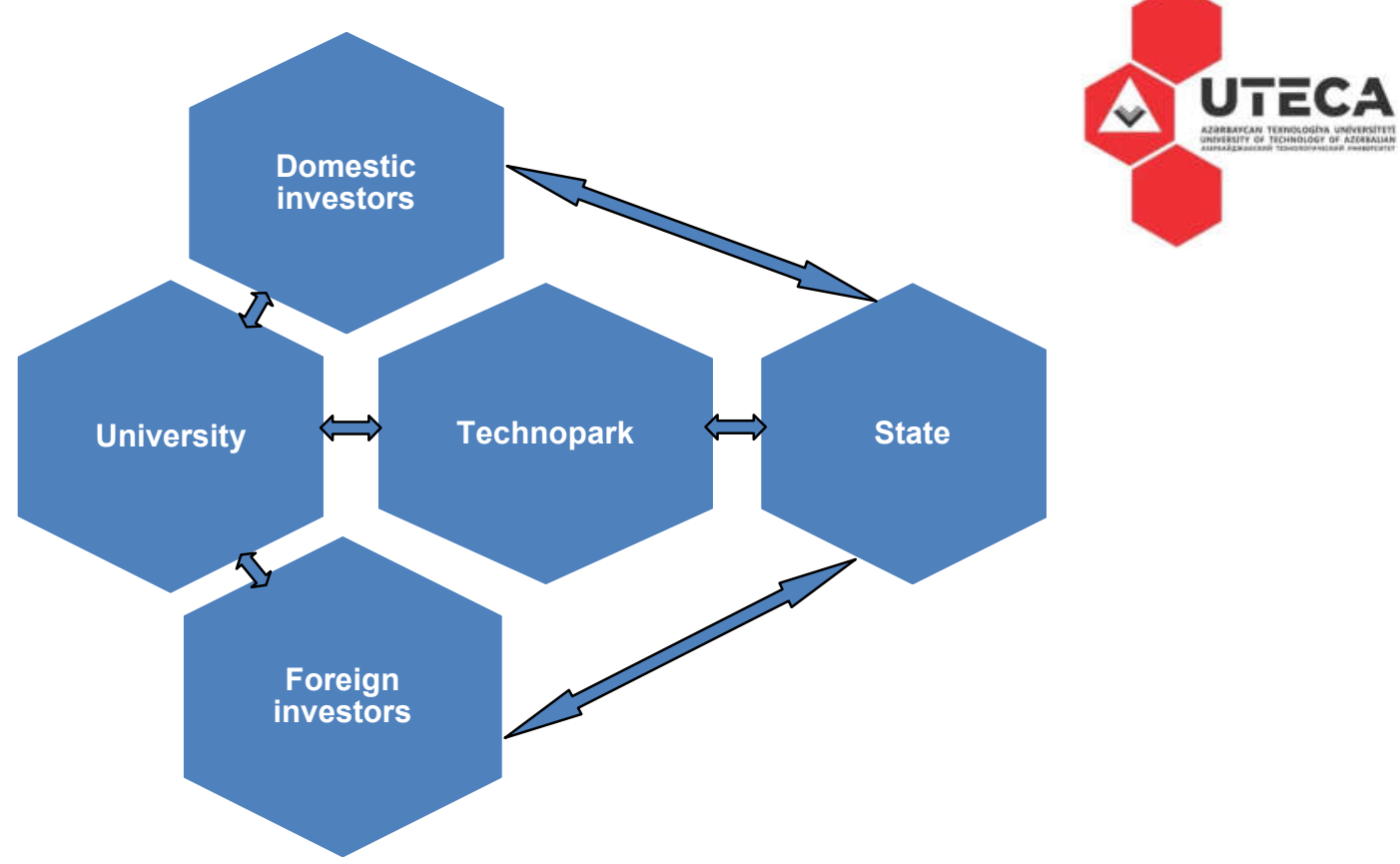

Figure 1 - Communication scheme of the technopark with the university

The term "industrial park" in literature is sometimes identified with the term "technological park". However, they should be distinguished, and to be more precise, a technopark is a form of territorial integration of science, education and production in the form of a union of scientific organizations, various departments, educational institutions, manufacturing enterprises or their subdivisions [3].

Naturally, in the creation of industrial parks, one of the main goals is to accelerate the development of the private sector, expand entrepreneurial activity. This goal in universities is of a scientific nature, i.e. technopark is a source of realization of innovative ideas, which, along with it, performs the function of uniting, aimed at the search and development of business connecting the university with production. In general, the technopark is characterized by applied activities to create a small production business for the implementation of new ideas of scientists, engineers and entrepreneurs.

In general, the technopark is characterized by applied activities to create a small production business for the implementation of new ideas of scientists, engineers and entrepreneurs.

It is known that, regardless of the volume, the development of university-industrial relations should be culminated by the creation of technoparks. For the reason that in the result of the unification of science and production, the overall potential of the university ultimately manifests itself in the educational process, the model of science-study-business should be periodically reflected in the technopark. The main result of applied scientific work should be reflected in the client-oriented program. Technopark in the university should be such an industrial center that students can go through real practice, become professional specialists. In the offices of technology transfer and client-oriented technopark, the creation of new products, improving the quality and productivity, reducing the costs, consulting services for advertising, marketing, training, education, business planning, strategic development and etc. is planned. As a result, industrial enterprises are united with scientific and research organizations on the territory of the technopark.

Depending on the nature and scope of the functions performed, five types of technoparks are known:

- Innovation centers. These centers provide mainly assistance to new firms working with high technology. It is an incubator for enterprises engaged in assembly and 
experimental-design work and provides organizations with financial support and assistance in solving technological and organizational issues.

- Scientific and research parks. These parks serve new and quite mature firms, maintaining close ties with universities or research institutes.

- Technological parks. These parks have at their disposal a whole network of knowledge-intensive firms and industries. But despite this, links with universities or research institutes are groggy.

- Technological centers. In other words, these are service enterprises created for the development of new high-tech firms. Their main task is to promote small-scale scienceintensive business.

- Conglomerates (belts) of technological and scientific parks. The purpose of these parks is to turn entire regions into high-tech zones. The most famous conglomerate is the well -known Silicon Valley. The valley consists of many diverse research organizations, institutes, science-intensive and service firms. At present, Silicon Valley has exhausted its spatial capabilities. Its new research and industrial companies are moving to cities north of it. There are three main differences between conglomerates: the individuality of organizational forms; ways of solving problems; functional purposes $[3,7]$.

It should be noted that along with these types of technology parks, network technology parks are also being created. Recently, their number is growing rapidly. And this makes it possible to redistribute potential economic and social benefits from the created technopark among the cities of the region. Thanks to the network structure, the capabilities of the technopark are increasing, the values of the performance indicators of its activity are improving, and the range of services provided to it is expanding. In addition, the network structure of the technopark gives the advantage of being present in large cities, universities or other territories that are significant for the development of the technopark [4].

Foreign experience [5] shows that the most effective mechanism for activating innovation in the high-tech market is the creation of a technopark zone (table).

Table 1 - Dynamics of development of technoparks in the world economy

\begin{tabular}{|c|c|c|c|c|c|c|c|}
\hline \multirow[b]{2}{*}{ Stages } & \multicolumn{7}{|c|}{ Criteria } \\
\hline & $\begin{array}{c}\text { Type of } \\
\text { technopark }\end{array}$ & Purpose & Kernel & Sponsors & $\begin{array}{c}\text { Type of } \\
\text { Products }\end{array}$ & basic service & $\begin{array}{c}\text { Leading } \\
\text { countries }\end{array}$ \\
\hline 1 & $\begin{array}{l}\text { Technopark of } \\
\text { the university, } \\
\text { regional } \\
\text { industrial } \\
\text { technopark }\end{array}$ & $\begin{array}{l}\text { Introduction of } \\
\text { research } \\
\text { development }\end{array}$ & $\begin{array}{l}\text { University } \\
\text { laboratories, } \\
\text { integrated } \\
\text { design and } \\
\text { research } \\
\text { departments }\end{array}$ & Universities & $\begin{array}{c}\text { Innovative } \\
\text { product }\end{array}$ & $\begin{array}{l}\text { Access to a } \\
\text { source of } \\
\text { knowledge } \\
\text { (university) } \\
\text { or source of } \\
\text { practical } \\
\text { tasks } \\
\text { (company) }\end{array}$ & $\begin{array}{c}\text { United } \\
\text { States, } \\
\text { United } \\
\text { Kingdom }\end{array}$ \\
\hline II & $\begin{array}{c}\text { Technological } \\
\text { incubators, } \\
\text { specialized } \\
\text { technology } \\
\text { parks, } \\
\text { technology } \\
\text { transfer centers }\end{array}$ & $\begin{array}{l}\text { The client- } \\
\text { oriented nature } \\
\text { of scientific and } \\
\text { technical } \\
\text { developments }\end{array}$ & $\begin{array}{c}\text { Office } \\
\text { complexes of } \\
\text { technological } \\
\text { incubators }\end{array}$ & $\begin{array}{l}\text { Governments } \\
\text { of countries } \\
\text { and regions, } \\
\text { municipalities }\end{array}$ & $\begin{array}{l}\text { Technologies } \\
\text { and } \\
\text { technological } \\
\text { solutions }\end{array}$ & $\begin{array}{l}\text { Rent of } \\
\text { premises }\end{array}$ & $\begin{array}{c}\text { European } \\
\text { countries } \\
\text { and } \\
\text { countries } \\
\text { in Asia }\end{array}$ \\
\hline III & $\begin{array}{l}\text { Network } \\
\text { technopark, } \\
\text { technoparks } \\
\text { community }\end{array}$ & $\begin{array}{c}\text { Creation of } \\
\text { spaces of } \\
\text { Internet } \\
\text { communities } \\
\text { for information } \\
\text { exchange } \\
\end{array}$ & $\begin{array}{c}\text { Virtual } \\
\text { networks, } \\
\text { network } \\
\text { departments } \\
\text { of technoparks }\end{array}$ & $\begin{array}{l}\text { Innovative } \\
\text { brokers and } \\
\text { agents and } \\
\text { investment } \\
\text { funds }\end{array}$ & Researches & $\begin{array}{l}\text { Access to } \\
\text { the } \\
\text { community }\end{array}$ & USA \\
\hline
\end{tabular}

Compiled on the basis of $[2,4,8]$.

The effectiveness of the implementation of scientific and technical products of universities can be enhanced by creating an innovative infrastructure with a specific functioning in the field of marketing management, i.e. regional technopark. Technopark as a way of interaction of scientific research institutions, universities and industry can be created from a network of independent infrastructure elements - business incubators. The universities of the region can organize on their own base business incubators for the 
development of small innovative enterprises engaged in the development of priority areas of science. The main task of the technoparks is to provide a multifaceted support to small innovative enterprises in the scientific and technical sphere and in the field of high technologies. This support is especially important at the initial stage of their formation. Analyzing the various definitions of the innovation structure under consideration, we can make the following generalization: technopark in the university is a scientific and production territorial complex, the main goal of which is to create the most favorable environment for client-oriented research results in the university and production sphere. The main function of technology parks is to generate, create, grow and bring scientific inventions and developments to the stage of customer-orientation, launching into production.

Exploring the technopark as a subject of economic activity, one can point to a number of economic activity, one can point to a number of features:

1) a platform equipped with everything necessary for the establishment and development of enterprises in the region, including small enterprises mastering innovative technologies. The ultimate goal of the activities of such enterprises is the creation of prototypes and the sale of science-intensive scientific and technical products that can be organized on the basis of the university;

2) financial independence, which ensures interest in the profitable management of the economy, that is, control and support activities of tenants of this technopark;

3 ) organizational and legal form - joint-stock company or association, where the founder may be the owner of premises transferred to the technopark; a bank or an enterprise that allocates the first funds for the organization and arrangement of an industrial park; Local authorities interested in the innovative development of the region; small innovative enterprises of technical universities;

4) consistent implementation of three important tasks: obtaining innovations, organizing technological transfer, client-oriented research results;

5) innovative business school.

In the technopark, scientific and experimental development of new competitive scienceintensive technologies is carried out. The ultimate goal of the Technopark's activity is to bring the scientific idea and high technology that has a high degree of risk to the stage of its introduction into mass production with the subsequent attraction of large financial investments for the production of the developed products.

Cooperation of specialized scientific centers and small innovative enterprises allows forming local scientific and production associations, continuously initiating scientific research, turning ideas into technological innovations, testing new technologies and introducing them into the production of high technology import-substituting products. At the same time, scientific research, connected with practice, becomes applied, and enterprises are enriched with scientific and technical achievements that increase competitiveness and product quality. The main direction is the development of customer-oriented technologies.

In the future, it is planned to launch a client-oriented technology program and support the creation of start-ups in universities and research centers, mechanisms for supportting the legal protection of the results of prospective commercial developments by development institutions, and implement measures on improving the efficiency of management on the results of intellectual activity. An important aspect of ensuring the economy leadership in the strategic direction of Azerbaijan 2020 is the quantitative growth of output of innovative products and the share of industrial enterprises engaged in the implementation of developments with a proportionate increase in research costs. The effectiveness of clientoriented processes of scientific and technical products of higher educational institutions can be enhanced by creating an innovative infrastructure with specific features of marketing management - a regional technopark. The International Association of Technology Parks offers the following wording: "A technology park is an organization managed by specialists whose main goal is to increase the well-being of the local community through the promotion of innovative culture and the competitiveness of innovative business and scientific organizations. 
To achieve these goals, the technopark stimulates and manages the flow of knowledge and technology between universities, research institutes, companies and markets. It simplifies the creation and growth of innovative companies with the help of incubation processes and processes of removing new companies from existing ones (spin-off processes). In addition to high-quality space, the Technopark provides other services [5]. Technopark as a way of interaction of scientific research institutions, universities and industry can be created from a network of independent infrastructure elements - business incubators.

The problem is that when it comes to the areas of high technology development, for some reason they forget about the most important thing, about people who, in fact, are the bearers of ideas, the sources of new knowledge. One of the main goals of creating technoparks is to support innovators, start-up entrepreneurs. The criterion for effective work of the technopark is the quantity and quality of small and medium-sized firms that they have produced, and the number of successful entrepreneurs known in the country and abroad. It is impossible to overestimate the role of technology parks for young professionals, graduates and university professors. For them it is not only the realization of their knowledge, but first of all, the opportunity to create their own business in a science-intensive sphere, the transformation of ideas born in the departments of the university into a specific scienceintensive product. That is why it is necessary that the government of the country, the Ministry of Education and the Academy of Sciences support university technopark.

In the presence of the domestic texnoparks it is impossible to ignore their experience, not to notice them, start creating new technoparks, forgetting about the existing structures. It is necessary to pay attention to their funding, experience and existing problems, so as not to repeat the mistakes already made. As was already mentioned above, the creation of new technological zones requires a strong stimulation of their creators and participants. Any participating party should feel the real impact of the project, thereby closing the circle, the center of which is the technopark. We believe that the weak development of the domestic market of science-intensive products is a hindrance to the successful operation of technology parks. Entering the international level of our, even prospective entrepreneurs, is difficult. But this problem also has its own solution.

The creation of a virtual university technopark can serve as a tool for expanding the space and involving in it not only Azerbaijani, but also foreign investors. Another difficulty encountered in Azerbaijan is the weak economic knowledge of potential scientific and technical entrepreneurs, their inability to confidently navigate the issues of accounting, marketing, management, international economic cooperation, as well as the lack of professional skilled personnel in the field of technology. Creation of a strong team of interested people who possess technical and economic knowledge in aggregate can contribute to the successful advancement of the activity of technoparks, and vice versa, the absence or underestimation of any of these components doom the business to failure in advance. One of the ways of recreating entrepreneurship in the field of science and technology in Azerbaijan is the way of creating university business complexes [6].

In our opinion, this idea can not be considered hopeless, because we are talking about including in the process of creating an industrial park an active part of the population, that is, students, doctoral students, young scientists. The university technopark can contribute to the development of creativity and entrepreneurship in the innovation sphere, will make it possible to increase the effectiveness of the practical focus of the founding institutions. One can not ignore the fact that, unfortunately, universities have a frugal financial potential to deploy a full-fledged technopark. One of the ways out is to create a virtual environment for supporting entrepreneurship. At the present time, universities are well equipped with information technology and computer equipment, which, in turn, can create not only virtual training courses, firms, but also a virtual technopark that can widely use the computer networks of founding universities, a global network, qualified staff support simultaneous efforts of several universities through cyberspace for the decision of those or other scientific, scientific and technical problems, technological or commercial problems.

The creation of a virtual technopark contributes to the solution of all the above problems. And first of all, it saves time on the way of development of high technologies, 
which, unfortunately, are not enough in our republic. Of course, the university virtual technopark can not, and should not be, a panacea for overcoming the technological backwardness of the country. Its creation, of course, will require an infusion of funds from the state and business, however, the main thing in the creation of the technopark is that its activities can give an impetus to the social and economic development of the Republic of Azerbaijan.

The purpose of creating a virtual joint technopark is to increase the efficiency and practical focus of scientific work carried out in founding universities, accelerate the implementation of innovative activities, promote the formation of private firms and companies created with the direct and indirect participation of teachers, scientists, engineers, doctoral students and university students, as well as Research Institutes. At the same time, the "virtuality" of the technopark provides it with wide use of computer networks of founding universities of a virtual united technopark, the Internet, universities' efforts through cyberspace, which allows to unite scientists from different universities within the target groups for the solution of various scientific, scientific- technological problems with the subsequent client-orientedness of their results.

Leading universities in the region can organize on their own base business incubators for the development of small innovative enterprises engaged in the development of priority areas of science. Technopark as an innovative structure with an orientation toward the implementation of marketing services will allow to solve such important tasks as obtaining innovations, organizing a technology transfer and customer-oriented research results.

The main goal of creating such a structure is to preserve the scientific potential of the region, ensure the comprehensive development of knowledge-intensive industries and increase the competitiveness of industrial enterprises at the city and regional levels.

Virtual Technopark is a specialized platform where scientific research, industrial enterprises, organizations and educational institutions representing knowledge-intensive, high technology, and innovative products are represented.

The basis of the exposition can be typical virtual platforms-stands of enterprises of participants, providing for the use of audiovisual display media of various advertising and marketing information, as well as technical documentation. Virtual platform, in fact, is an event for the identification and presentation of technologies, the development of which in production will provide enterprises and entrepreneurs of the city and region with competitive advantages in commodity markets and will allow effective promotion of scientific and technical products. Characterizing the innovation process in general terms, it is possible to present it as obtaining and client-orientation of the invention, new technologies, types of products and services, decisions of industrial, financial, administrative or of any other character, and other results of intellectual activity. If we consider a part of innovation activity in the form of an innovative project, we can distinguish two interacting parties - a university (a small innovative enterprise) and an external partner (entrepreneur). Intra-university work can be structured as an actual scientific research work of an applied nature and development of the technology of products production. The activity of an external partner is related to the development of output, the organization of marketing activities for the transition to mass production, the receipt of payment from customers and the receipt of funds to the settlement account of the university (sub-account of a small enterprise). At the same time, the entrepreneur assumes the main group of risks arising in the process of client-oriented project. The client-oriented nature of research activity is largely determined by the links between key participants in the innovation process - scientific organizations and universities, small firms, large corporations [6, 7].

It is proposed to create a virtual technology park on the basis of UTECA (Azerbaijan Technological University) with the involvement of various financial resources based on the interaction of small innovative enterprises. To build a technopark as a physical object, investments are needed for production areas, premises, transport. Creation of a virtual technopark based on UTECA will be an information space that unites small enterprises of the region at a distance, there will be less investment, on domain registration, hosting, site creation. A virtual technopark will unite various universities, scientists, one and the same 
researcher, for example, can participate in several projects, developments and can be not only at the level of the region. If the entrepreneur wants to become a user of the technopark, he will need to get a virtual office at his disposal. Then you need to create a virtual exhibition, and in the end - to enter into real contracts and receive real money. The Technopark, located in the information space, will facilitate the unification of various innovative infrastructures that are territorially separated, will allow the same researchers to participate in several projects of various organizations, will increase the effectiveness of innovation activities within the region.

The formation of a virtual technopark in the region will help to solve existing problems and increase the economic and innovative potential of the university. The creation of a virtual industrial park causes the emergence of a number of advantages that are of great importance for the economy of the region, including the university: a reasonable investment of funds; the emergence of new jobs, the unification of several business technologies in one infrastructure, and, finally, the streamlining of traffic flows [8].

An important consequence of the creation of the technopark is the synergy of several technologies in the links of one economic chain: scientific development, implementation of prototypes, cooperation of small, large and medium-sized businesses, marketing research, exposition and exhibition opportunities and potential implementation.

A virtual technopark created on the basis of a university in the region will contribute to strengthening the interaction of the main market actors in the direction of customer-oriented innovation, positioning and promotion of scientific and technical products in Azerbaijan and abroad, and thereby increase the economic and innovative potential of the republic.

In the process of diffusion of innovations, the question arises as to the degree of perception of the results of intellectual activity by entrepreneurs. First of all, the result of client-oriented scientific and technical development interests the entrepreneur from the point of view of gaining profit from the introduction and implementation, taking into account a significant share of the risk associated with activities on new types of the market or offering a new product.

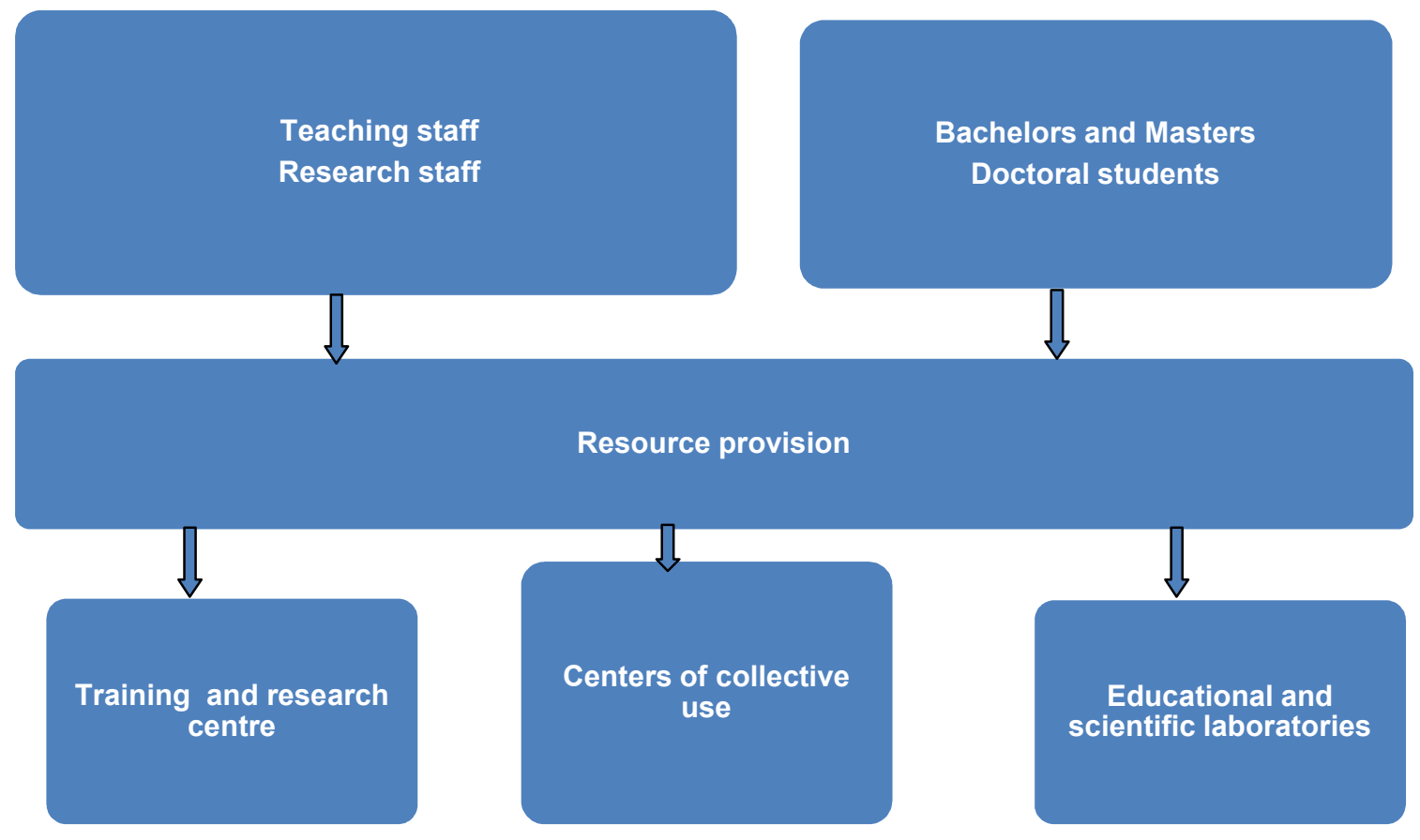

Figure 2 - Innovative model of the university

Unfortunately, in Azerbaijan the processes of creation and management of technological projects have not yet reached the world level. What is being implemented today in the field of technology parks, as it is indicated above (the table), refers to the first or maximum to the second stage of development of technoparks. However, to create 
technoparks of the 1 st and 2 nd stages of the development of technoparks, large premises, entire buildings with special equipment are needed. This requires large investments. A more effective solution of this problem is possible when creating technoparks of the third stage of development in the form of virtual technology parks. In this direction, Europe is moving forward. For example, the European Union plans to create a virtual distributed technology park "European Technological Institute" (EIT). This article describes the concept of creating a virtual distributed technology park as a technopark of the third stage of development based on the most advanced technologies and solutions tested in Europe.Analysis of innovative resources UTECA allowed to form an innovative model of the university, which includes the following structural elements, presented in Fig. 2.

Experience shows that it is in these structures that the innovative resources of the university are concentrated: unique scientific and educational equipment, modern information and communication technologies, and modern educational and methodological complexes. In addition, in such structures the intellectual potential of the university is concentrated, including experienced teachers, highly qualified and possesing modern skills for working with complex high-tech complexes engineering - technical personnel, as well as talented students and doctoral students.

Lets consider the general principles of the organization of university virtual technoparks. In the beginning, it should be noted that the main purpose of the system of a university virtual technology park is the information association of numerous subjects engaged in educational and scientific activities, i.e. creation of "information- subspace of education, science and hi-tech innovationtion business'. This subspace is formed as the intersection of the country's common information space (cyberspace) and the global scientific and educational information space. The main blocks of the university virtual technopark are shown in Fig. 3.

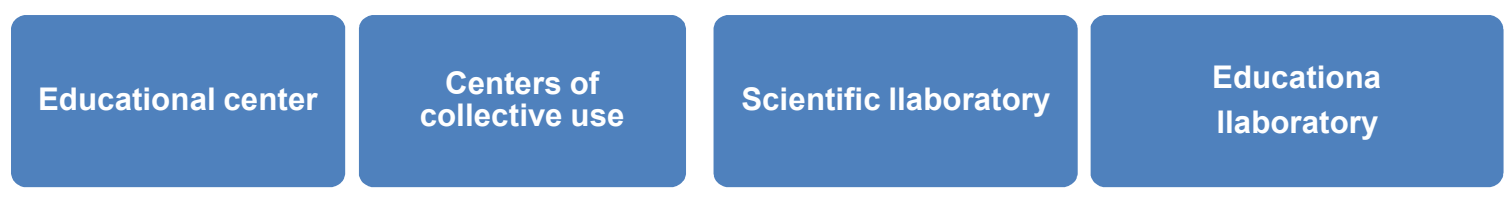

\section{University Infrastructure}

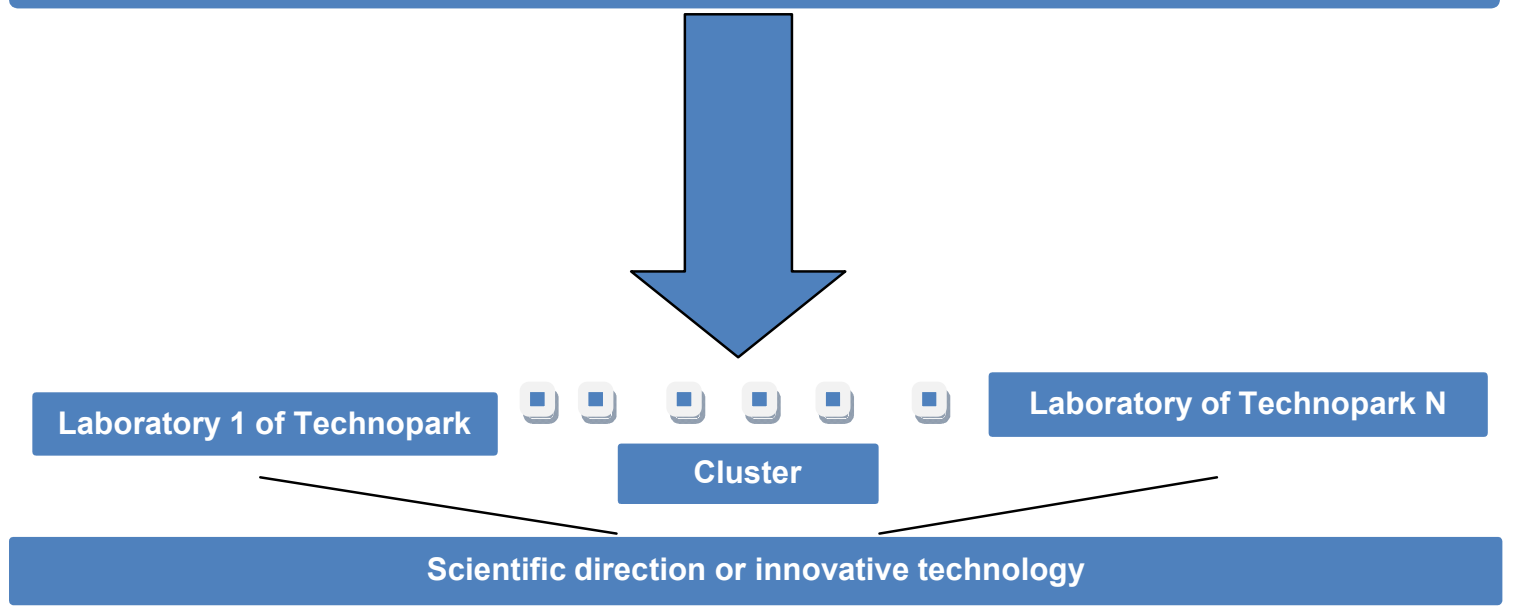

Figure 3 - The main blocks of the technopark

The main element of the technopark is a laboratory that can be implemented as real equipment or as a virtual laboratory (network application or network service). At the same time, considering that the laboratory is the main component and the shared resource of a virtual technopark, the problem of standardization of this element arises. An effective solution to this problem will make it easy to integrate, reconfigure and scale up the information 
resources of the technopark. The functional structure of the laboratory, the list of services provided by the laboratory, the interface between the remote user and the services of the laboratory, the composition and structure of the remote access node, including the number of network ports, routing protocols, requirements to the communication links (bandwidth, latency, packet loss, variation in packet delay, etc.) can act as objects of laboratory standardization. In our case, cluster is the unification of laboratories in the scientific areas or in accordance with innovative technologies. For example, the integration of various areas of scientific activity, including mathematical modeling of nanoobjects, experimental studies using unique equipment and the production of nanostructures are necessary for the realization of nanoproducts. Therefore, such integration is possible within the nanotechnology cluster, which includes the laboratory of mathematical modeling and the laboratory of nanotechnologies.

Lets consider also the logical organization of a university virtual technology park. Modern virtual technology parks have a hierarchical cluster organization (Fig. 4).

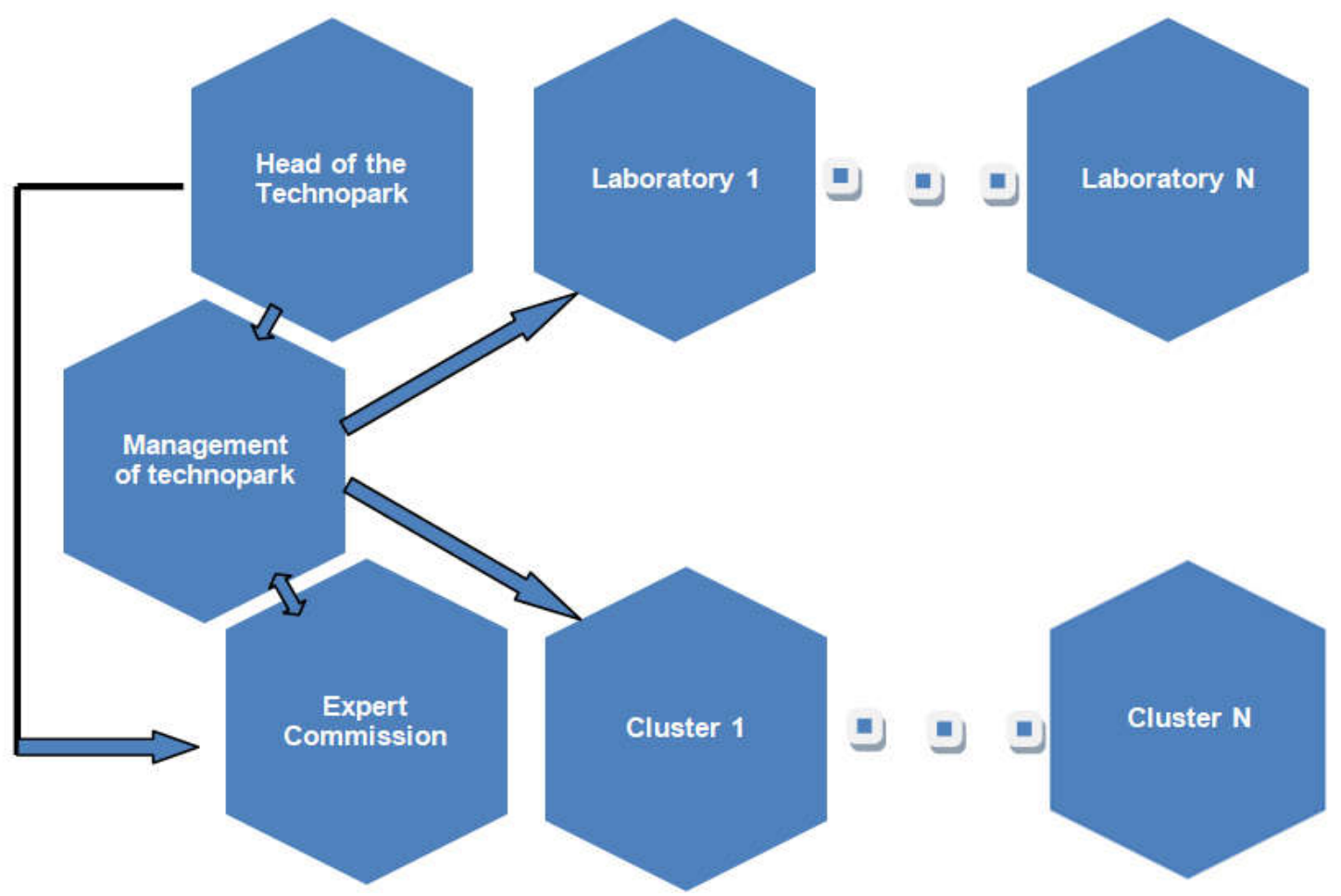

Figure 4 - Organizational structure of a virtual technopark

The definitions of the laboratory and the cluster of technopark were given earlier.

Here it is necessary to dwell more on the logical organization of the technopark. To implement the lower level of the technopark (the level of laboratories and clusters) it is proposed to use the virtual local area network (VLAN) technology. VLAN provides the ability to create logical groups of users or groups of laboratories on the scale of a virtual technology park. At the same time, the management of the technopark can organize laboratories in logical groups (clusters) regardless of the physical location of the laboratories. This is one of the main advantages of this technology - the ability to create clusters based on the direction of research or innovation activities of users of the technopark, without being tied to the network topology. Such organization of clusters allows to increase the efficiency of users of the technopark. VLAN technology provides a number of advantages:

- simplicity of reconfiguration of a logical or organizational structure of Technopark;

- adding or removing laboratories and clusters;

- use of limited resources of the technopark;

- high level of security. 
The average level includes management of the technopark and an expert commission. The functions of the technopark managers include: solving the problems of scaling the technopark, reconfiguring the organizational structure of the technopark in accordance with the changing research program of innovative projects being implemented in the technology park, adding or removing laboratories and clusters. To carry out an independent scientific and technical expertise of innovative projects, expert commissions are being set up for scientific consulting of users in the technopark. Expertise and consulting is carried out in the on-line mode. The highest level of the technopark is the leadership, which includes representatives of the Ministry of Education or the Academy of Sciences of the Republic of Azerbaijan, Ministry of Industry, UTECA, i.e. those institutions that have integrated their innovative resources into the technology park.

The business component of the technopark or the platform of a virtual technopark should provide:

- search for partners implementing the business ideas;

- creation of a team for the implementation of the project;

- search for a laboratory or cluster for project implementation;

- implementation of the project in the technopark.

In Fig. 5 presents the algorithm for promoting a business idea from the moment of its inception to the moment of its implementation in the form of an innovative product and its subsequent client-oriented approach. Cluster structure of the technopark on the basis of modern network technology (VLAN, VPN, WAN, etc.) allows to implement effectively the procedure for promoting innovative business ideas in the technopark.

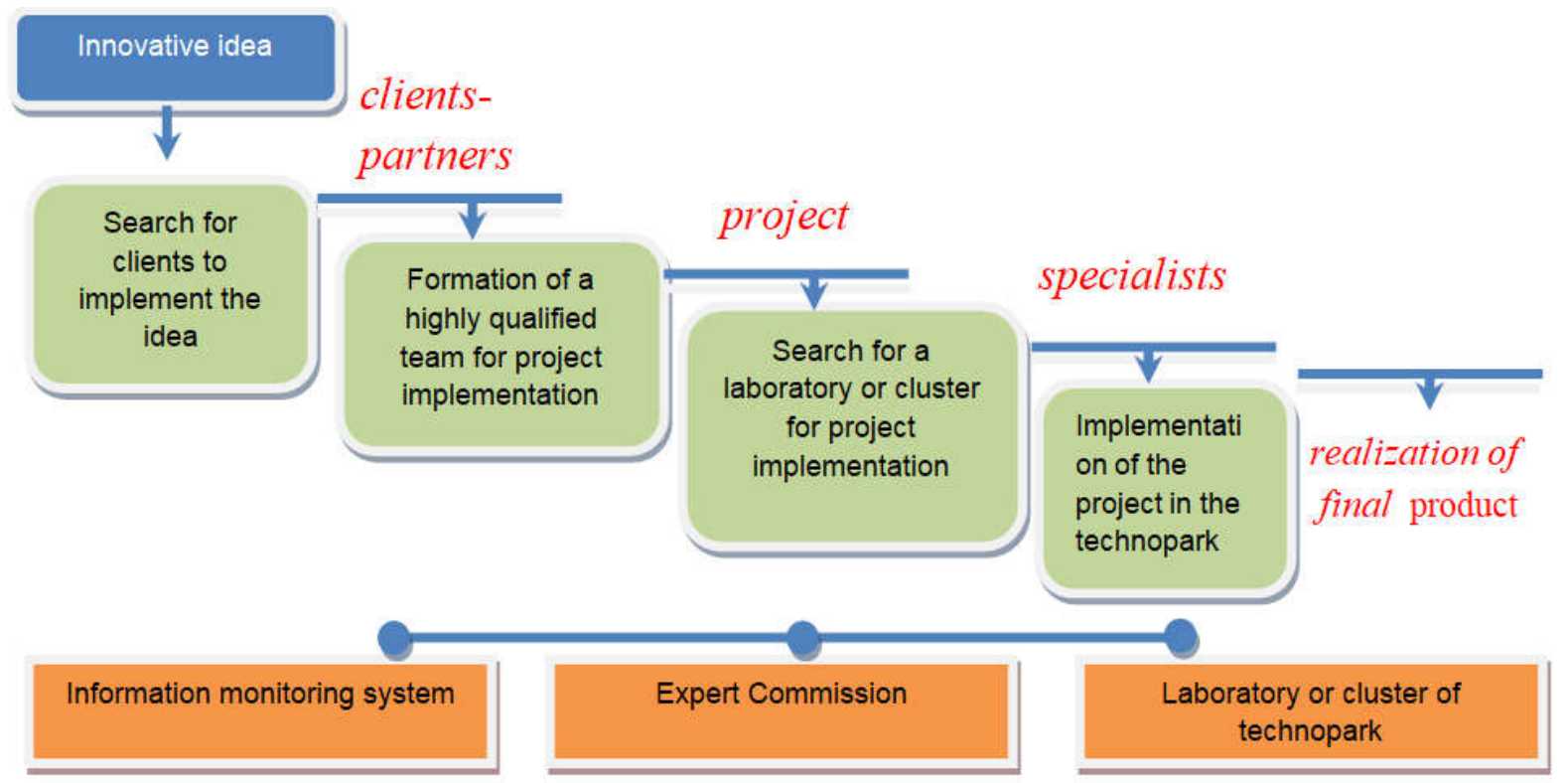

Figure 5 - Scheme of client-oriented innovation ideas in the technopark

One of the main components of the technopark is the educational component. As educational potential is concentrated in innovative structures of the university, it certainly needs to be integrated into the virtual information environment of the technopark for the implementation of educational services of the technopark, for example, educational consulting, professional development, and development of entrepreneurship skills of users of the technopark. Therefore, the platform of a virtual technopark should provide educational services. At the same time, distance learning technologies will be used, including technologies of network virtual means and interactive multimedia (video on demand, interactive television, videoconferencing).

Speaking about the peculiarities of the virtual united university technopark being created, it should be noted that the creation of a virtual joint technopark should be preceded 
by a careful study not only of the scientific and entrepreneurial potential of universities and research institutes, i.e. participants, not only detailed elaboration of the concept and guarantee of the participants, but also the creation of a group of prospective entrepreneurs from among inventors, engineers, technologists, students, doctoral students, teachers and scientists of universities, other organizations related or ready to be bound by contractual relations with the technopark and its founders, a ready-made package of technologies intended for client-orientedness should be formed. In fact, several, and sometimes several dozen projects are preliminary worked out, which can bring profit in the coming years. So it turns out that the virtual aspect of the university technopark's activity consists not only in providing financial services to all willing entrepreneurs and in collecting in surplus their development in one database, which, as practice shows, with a high degree of probability, will remain unclaimed, but also in detailing all aspects of the creation of the company, its product and determine the market for its implementation even before the creation of the company itself and its material and financial support.

The implementation of the concept of creating a university virtual technology park proposed in this article will contribute to the expansion of the innovative segment of the Azerbaijani economy, client-oriented innovation projects, shortening the time at project development stages, improving the quality of project teams, attracting international experience and experts, significantly increasing the chances of technology projects.

Conclusion. Our university UTECA has a unique scientific potential. This potential is students, youth receptive to everything new. To this potential it is necessary to add considerable experience of the teaching staff in the organization of academic work, as well as fundamental and applied scientific research. In spite of the above mentioned difficulties, it is necessary to dispose of this powerful potential, to stop stream production of personnel, and to do everything to give graduates not only a diploma, but also a real opportunity to do their own work, for example, in a university virtual technopark. We do not consider this concept exhaustive, these are only the first attempts, the beginning of further careful study of the issue. The problem of creating innovative entrepreneurship and the infrastructure of its support is of a complex character and can not be solved solely by the forces and resources of the university. To solve it, we need legislative support, broad support of business circles in general, we need much of that that we do not have today. And yet, you need to act.

\section{REFERENCES}

1. Süleymanov A.Ş. Texnoparkların yaradılması universitet-sənaye əlaqələrinin əsas istiqamətidir. // Modern problems of university-industry realtions in Bologna educational process İnternational symposium. Gəncə, UTECA, 2016.

2. Problemy i resheniya: biznes-inkubatory i tekhnoparki Rossii [Elektronnyy resurs] // Rezhim dostupa: https://www.rusventure.ru/

3. Rayzberg B.A. Sovremennyy ekonomicheskiy slovar' / B.A. Rayzberg, L.SH. Lozovskiy, E.B. Starodubceva. - M.: Infra-M, 2015. - 511 s.

4. Rybkina, A.S. Industrial'nye parki kak instrument formirovaniya kachestvennoy institucional'noy sredy regionov // Upravlenie ekonomicheskimi sistemami: elektronnyy nauchnyy zhurnal. - 2014. - № 4 (64). - s. 1-17.

5. Economic zones in the ASEAN / UNIDO. - UNIDO country office in Viet nam // Official cite of UNIDO [Electronic resource] / UNIDO. - Hanoi, 2015. - Mode of access: https://www.unido.org/fileadmin/user_media_upgrade/Resources/ Publications/UCO_Viet_Nam_Study_FINAL.pdf. - Date of access: 12.05.2016.

6. Azərbaycan Texnologiya Universitetinin (UTECA) 2016-2020-ci illər üzrə inkişafının strateji planı. Gəncə, 2016.

7. Semenova I.V. Sovremennye problemy formirovaniya tekhnologicheskih zon $v$ Rossiyskoy Federacii. ZHurnal Vestnik Sankt-Peterburgskogo universiteta. 2009

8. Radygina S.V. Sozdanie tekhnoparkov kak instrument razvitiya innovacionnoy deyatel'nosti regiona / S.V.Radygina // Vestnik Udmurtskogo universiteta. - 2014. - №2, 3. - s. $46-49$ 